تغييرات فيبرونكتين در ماتريكس خارج سلولى كليه به دنبال دريافت نيكوتين در دوره زندكى جنينى

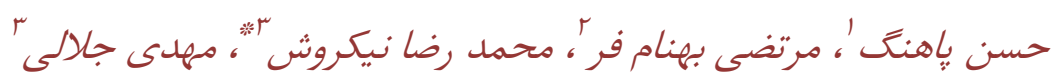

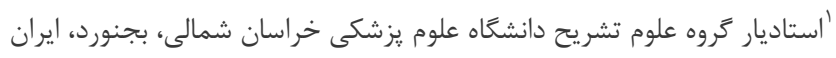

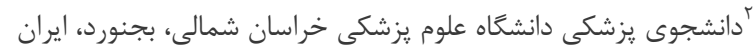

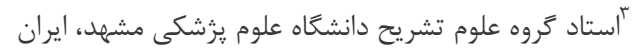

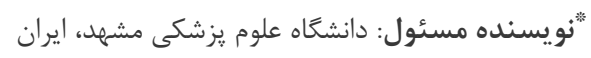

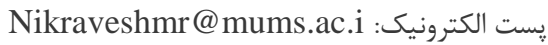

جكيده

زمينه و هدف: با وجود هشدارهاى فراوان هنوز هم ها تا •r\% زنان باردار به سيًار كشيدن علاقه دارند.

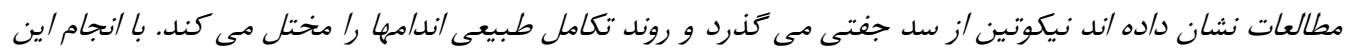

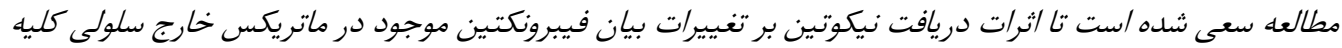
نوزادان يكى روزه موش بررسى شود.

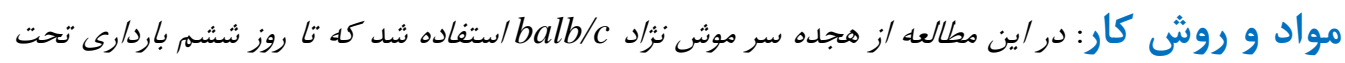

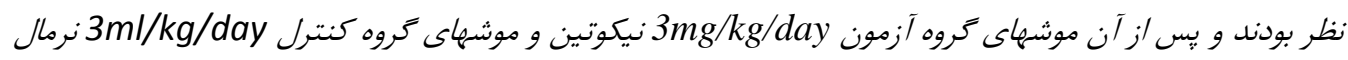

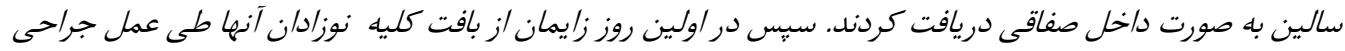

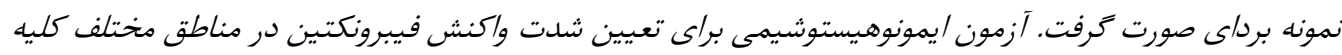

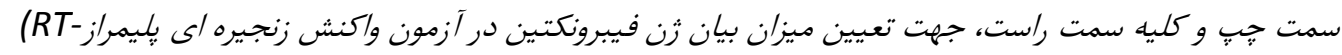
(PCR)

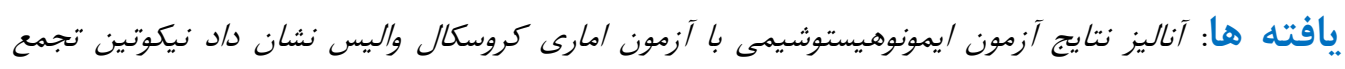
فيبرونكتين رابه طور معنى دارى در ماتريكس كلومرول ولوله بيجيده بروكزيمال افزايش مى دهد (0.05>م) و ونتايج آزمون RT-PCR نيز /ين يافته را به اثبات رساند.

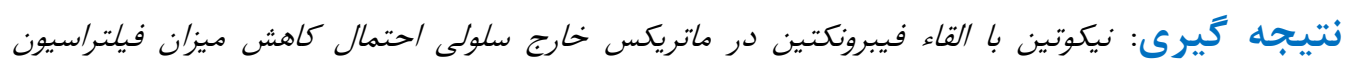

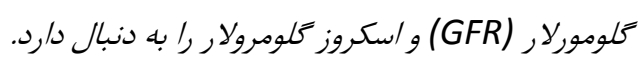

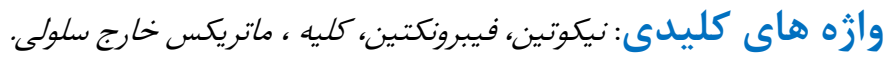

وصول: • اصلاح:

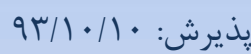


جهت انجام اين يزوهش از 11 سر موش ماده بالغ نزاد

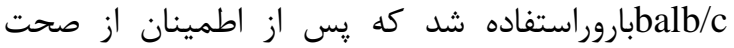

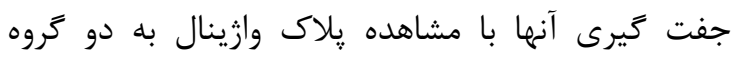
آزمون و كنترل تقسيم شدند و از روز ششم باردارى به به به باله

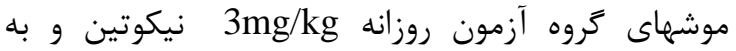
موشهايى كه در تروه كنترل قرار داشتند 3ml/kg نرمال سالين به صورت داخل صفاقى تا پايان دوره باردارى تزريق

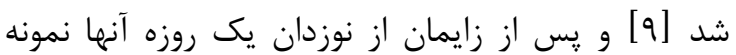
بردارى صورت كرفت به طورى كه كليه سمت راست آنها

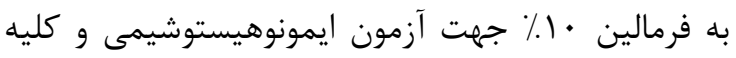

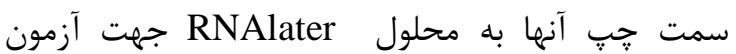
واكنش زنجيره اى يلى مراز (RT-PCR) منتقل شد.

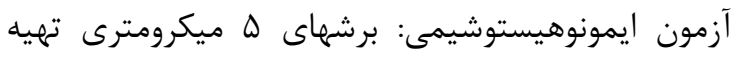

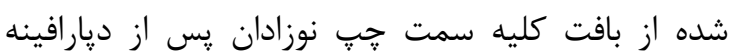
شدن در كزيلل در اتانول با درجات نزولى آب دهى شدند سبس به مدت ها دقيقه در محلول يراكسيد هيدروزن

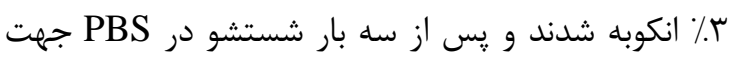

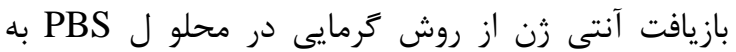

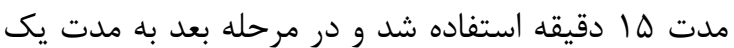
ساعت در معرض آنتى بادى آنتى فيبرونكتين قرار كرفتند

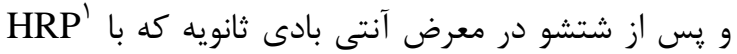

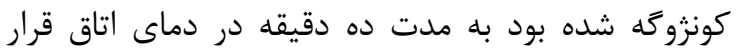

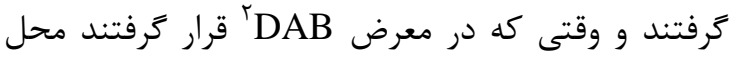
هاى واكنش به رنگ قهوه اى نمايان شد و جهت جلوكيرى از واكنش بيش از حد دو بار در آب مقطر شتشو

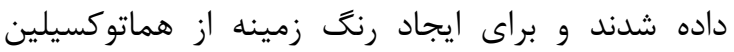

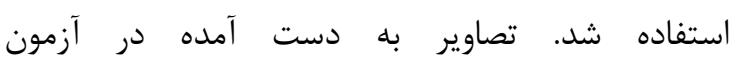
ايمونوهيستوشيميايى با متد رتبه اى كيفى طبق جدول

$$
\text { زير آناليز شدند: }
$$

آزمون واكنش زنجيره ايى يلى مراز در زمان زئ زئ واقعى: بيان

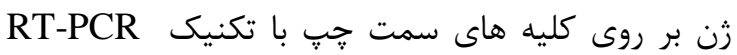
انجام شد. براى اين كار يُ إز اينكه نمونه كليه هاى

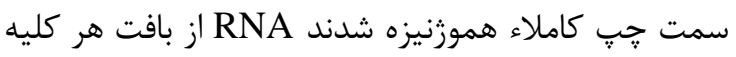
توسط RNX-plus طبق دستور شركت سازنده استخراج

1 -horseradish peroxidase

2- diaminobenzidin
على رغم تلاشهاى صورت گرفته و افزايش سطح آخاهى مردم در زمينه اثرات سوء سيعار در دوران زندگى جنى جنينى سيعار كشيدن همجنان يكى از عادت هايى است كه

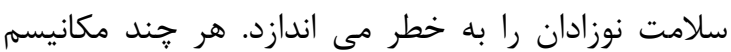
دقيق ارتباط بين سيعار كشيدن مادر و بيماريهاى متعدد حاصله از آن به خوبى كشف نشده است [ـ [1]. ولى تاكنون مشخص شده است كه بين سيگار كشيدن مادر در دوره بارداى و سيعارى شدن نوزادان ارتباط معنى دارى وجود دارد و نوزادانى كه از مادران سيگارى متولد مى شوند مستعد افسردگى و كاهش ضريب هوشى هستند و زمينه يرخاشگرى در آنها افزايش مى يابد [ب]. در مطالعات ديخرى اثرات تراتوزنيك نيكوتين در دوره باردارى به اثبات رسيده و نيكوتين منجر به نقايصى از جمله شكاف كام و لب شده است و يس از بررسى بيان زنهاى متعدد و و مسيرهاى سيخنالينگ مشخص شد ماتريكس خارج سلولى نقش عمده اى در اين فرايند ايفا مى كند [س]. و در ياره اي از مطالعات تاثير سيعار در دوره حاملغى بر عدم عدم رونويسى زنهاى مولكول هاى اتصالى موجود در ماتريكس

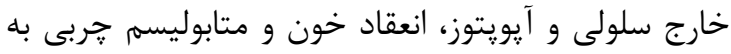

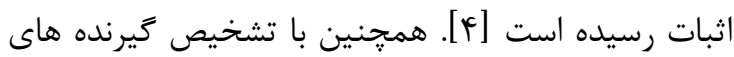

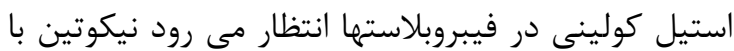
تغيير در بيان كليكويروتئين هاى متعدد سنتز شده توسط اين سلول ها تكامل ارعان ها را تحت تاثير قرار دهد [هان]. مثلا تحقيقات كذشته نشان داده اند نيكوتين مادرى بيان

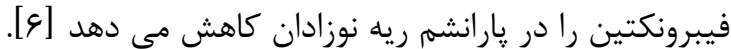
و با توجه به اينكه اجزاء ماتريكس خارج سلولى از قبيل فيبرونكتين، كلازن و لامينين در شكل گئرى ساءله ساختمان كليه در طى اركانوزنز نقش به سزايى دارند و ساختمان

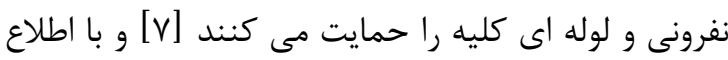
از اين موضوع كه عوارضى مثل ضخيم شدن غشاء يايه

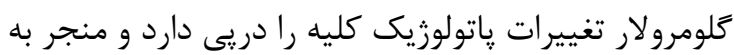

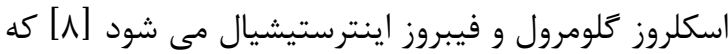
سلامت انسان را به خطر مى اندازد لذا در اين مطالعه سعى شده است تا اثرات دريافت نيكوتين در دوره زندگى إنى جنينى بر روند تغييرات فيبرونكتين موجود در ماتريكس خارج سلولى كليه در دوره تكامل مورد بررسى قرار گيرد. 


\begin{tabular}{|c|c|c|c|c|c|}
\hline رنخ بسيار قوى & رنخ قوى & رنَ متوسط & رنگ ضعيف & بدون رنگ & شدت رنخ \\
\hline$f$ & $r$ & $r$ & 1 & - & رتبه \\
\hline
\end{tabular}

با مشاهده احشاء نوزدان مورد مطالعه هينج گَونه ناهنجارى

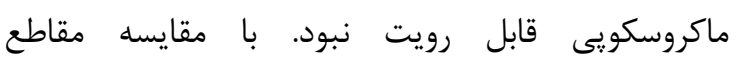
ايمونوهيستوشيميايى بافت كليه در دو كروه مشاهده شد بد بيشترين تغييرات واكنش فيبرونكتين در ناحيه كلومورل و

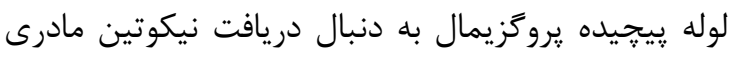

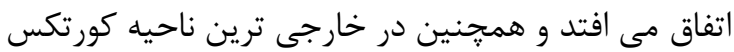
كليه كه بلافاصله در زير كيسول قرار دارد نيز تفييرات واضحى قابل رويت بود (نمودار ب- شكل بل ().

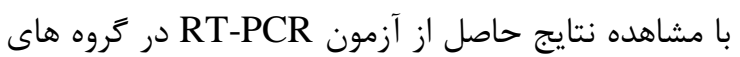
مورد مطالعه شاهد افزايش بيان mRNA فيبرونكتين در آنان آنان

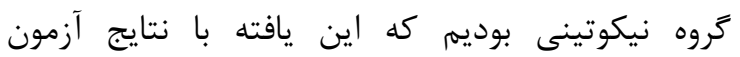
ايمونوهيستوشيمى مطابقت داشت (نمودارَ).

مطالعه حاضر نشان داد نوزادان موشهايى كه در معرض

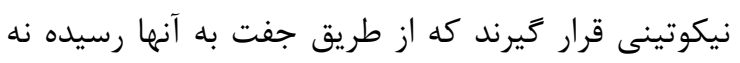

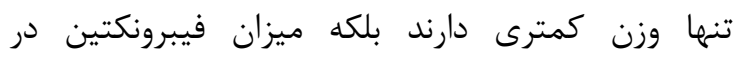
ماتريكس خارج سلولى كليه افزايش مى يابد. مطالعات

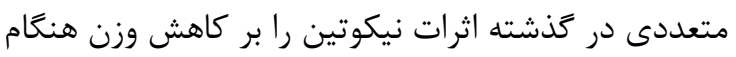

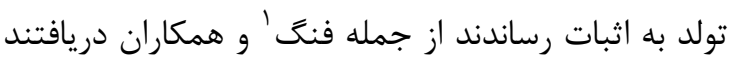
نوزادانى كه در دوره حاملكى نيكوتين دريافت كردند وزن

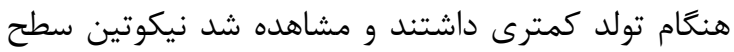

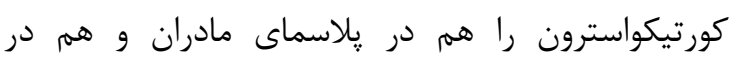
يلاسماى نوزادان افزايش مى دهد و يكى ارتباط مستقيم

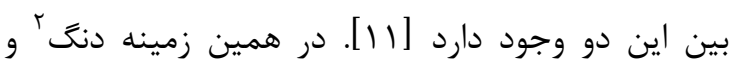

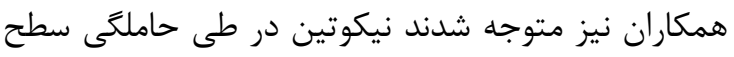

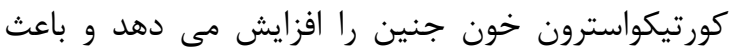

1-Feng

2 -Deng

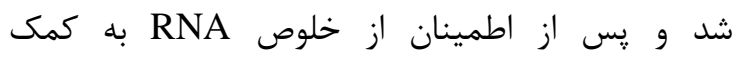
الكتروفورز روى زل آتاروز رونويسى معكوس با استفاده از كيت سنتز cDNA انجام شد و در نهايت واكنش زنجيره

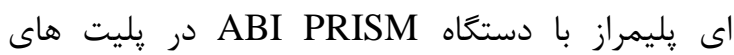

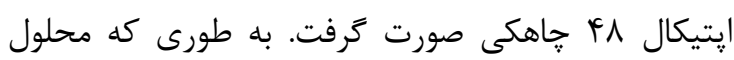

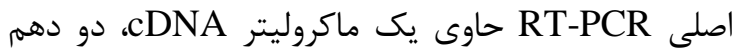
ماكروليتر يرايمر آغازى و دو دهم ماكروليتر يرايمر ئر معكوس و سه و شش دهم لهم ماكروليتر آب ديونيزه و وينج

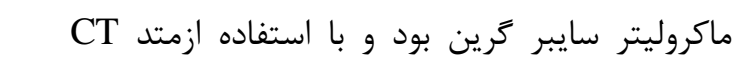

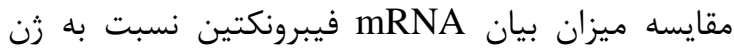

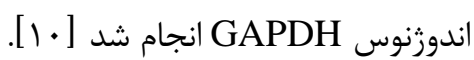

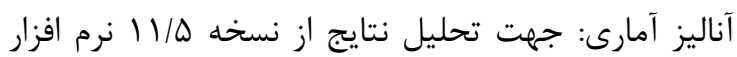
SPSS

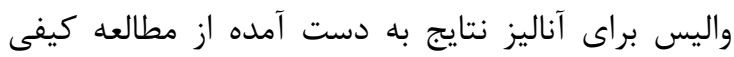
ايمونوهيستوشيمى بكار رفت و براى مقايسه نتايج مطالعه كمى RT-PCR از تست آمارى Vمتر از هـ • • از نظر آمارى به عنوان معنى دار در

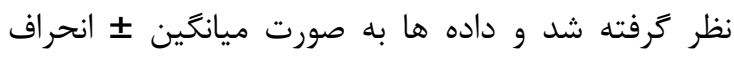
معيار نمايش داده شدند.

\section{يافته ها}

با مقايسه ميانكَين وزن نوزادان يك روزه دئ در كروه آزمون

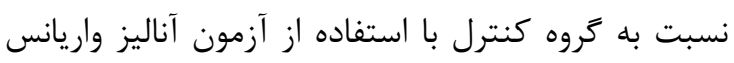

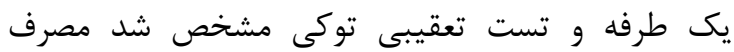
نيكوتين در دوره باردارى به طور معنى دارى وزن نوزادان

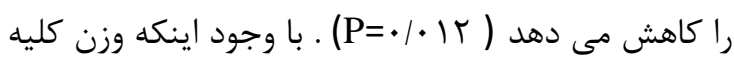

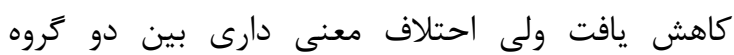

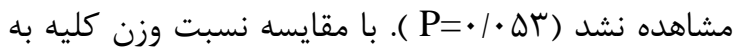
وزن بدن مشخص شد كروه نيكوتينى كاهش معنى دارى را نسبت به كروه كنترل دارد (نمودار ()). 


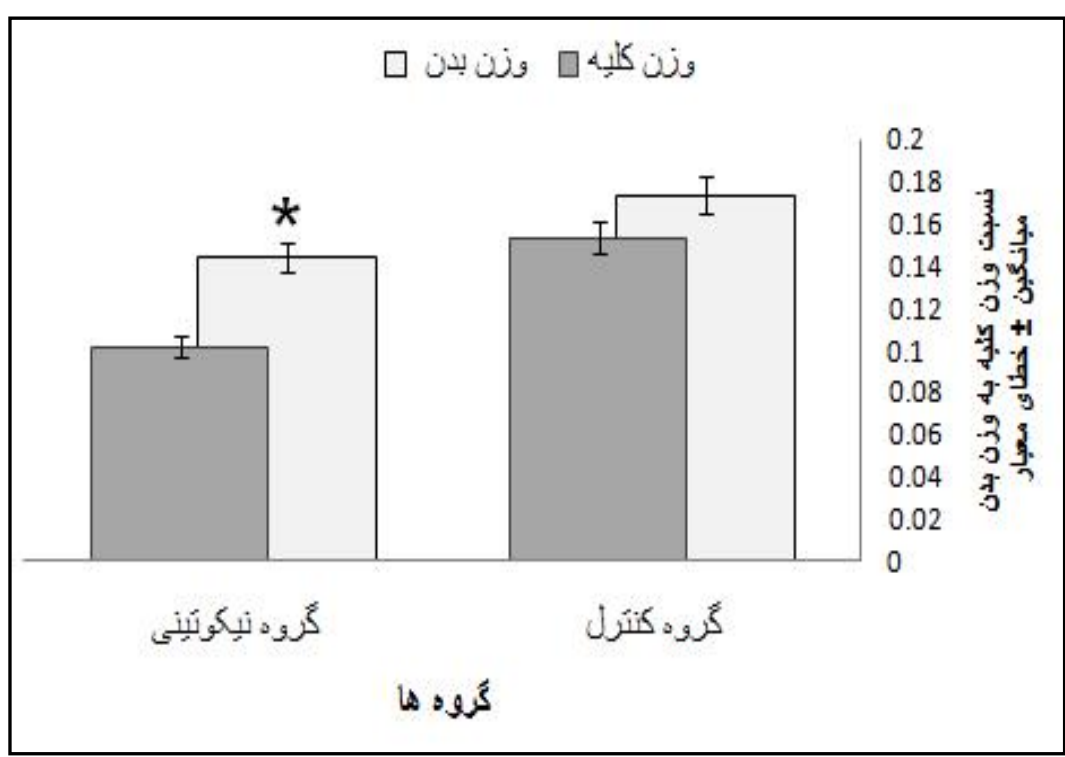

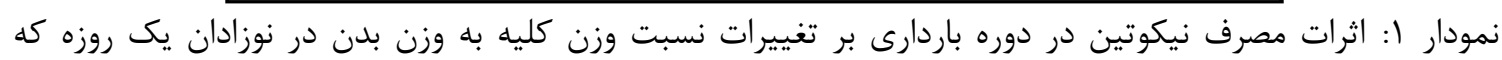

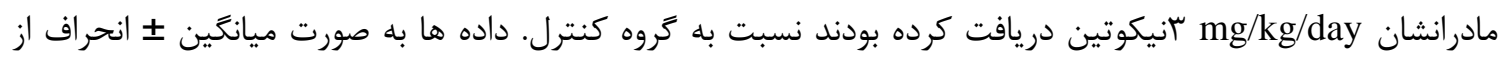

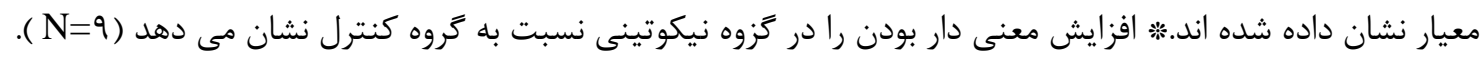

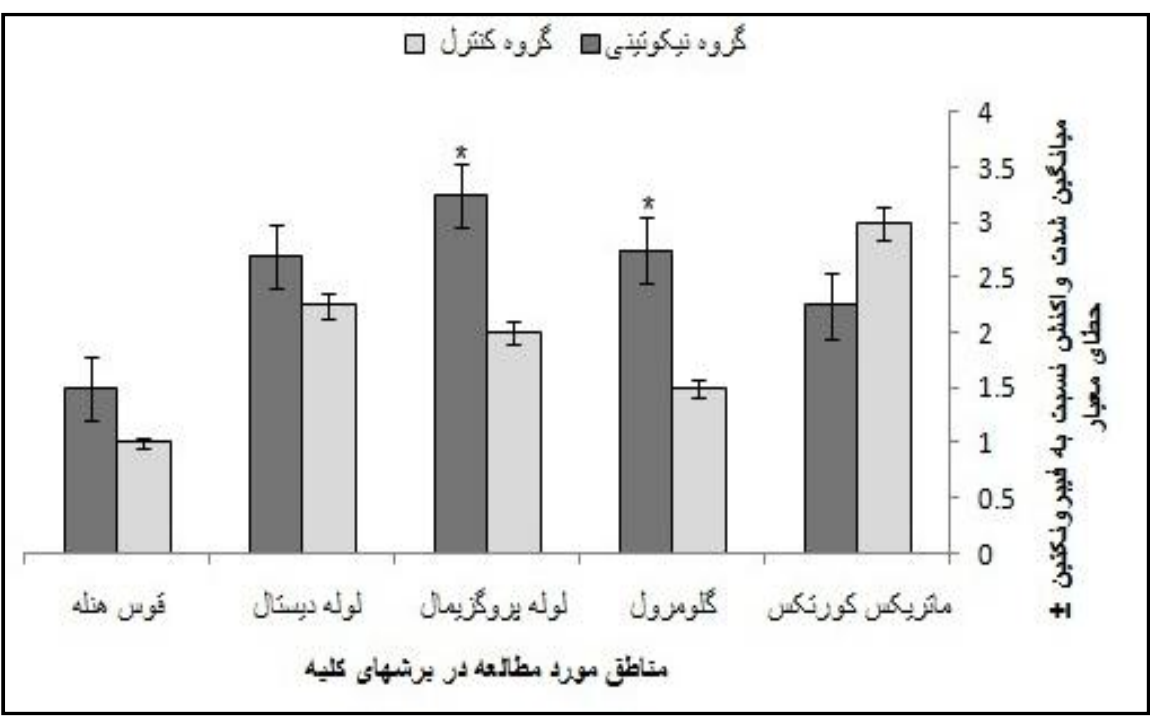

نمودار rا: اثرات نيكوتين بر شدت واكنش فيبرونكتين موجود در ماتريكس خارج سلولى نواحى مختلف

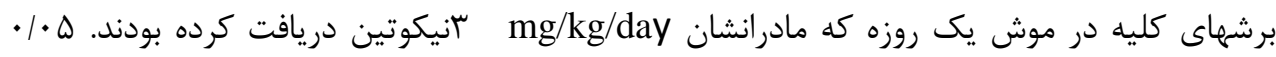

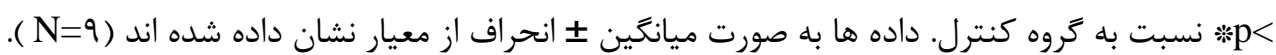



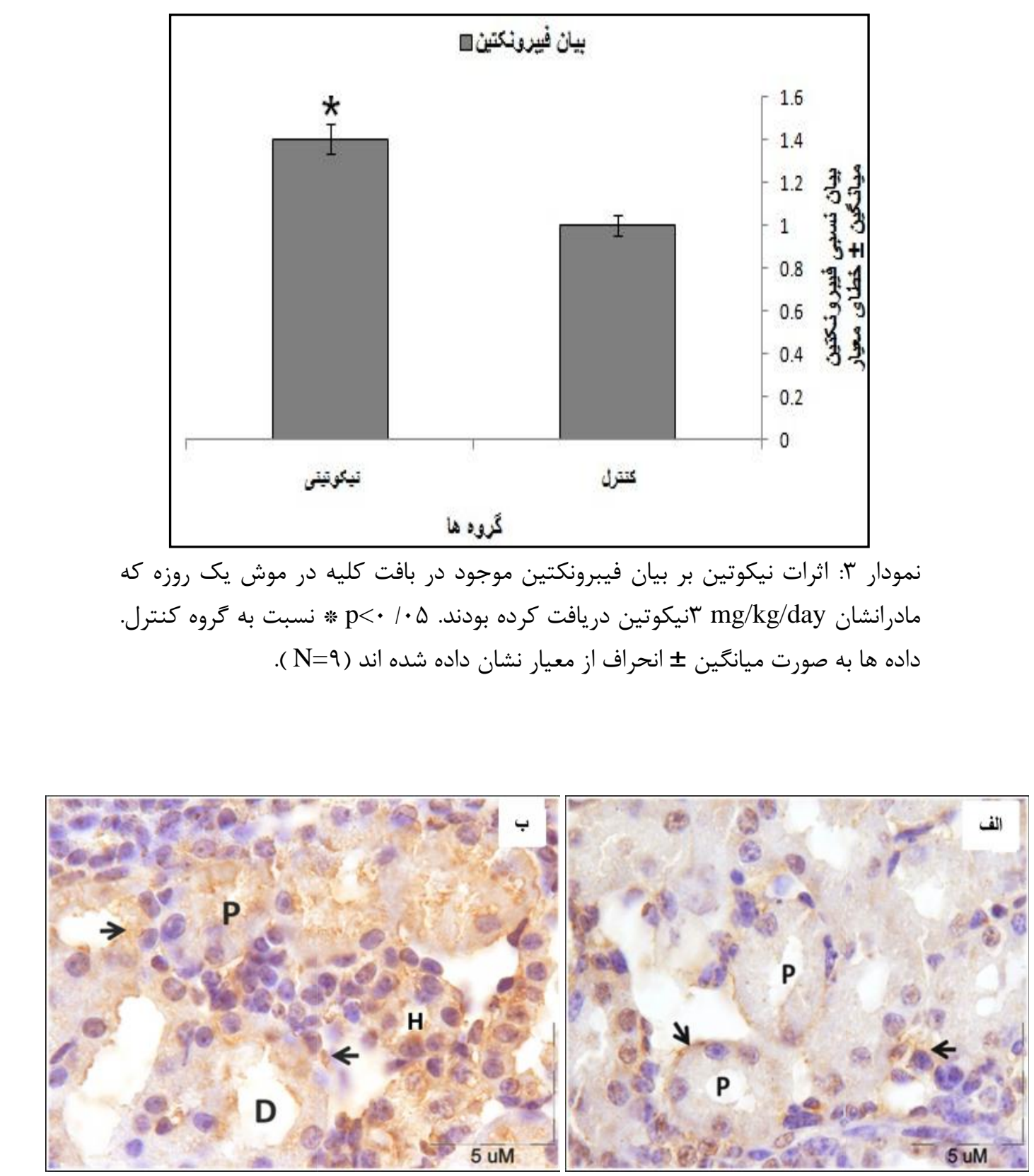

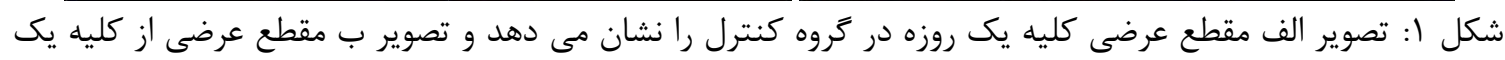

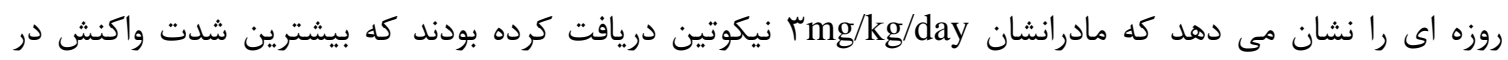

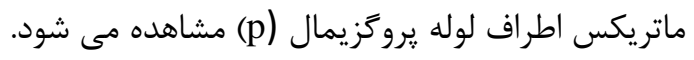


مبدل بتا و يروتئين هاى ماتريكس خارج سلولى مثل فيبرونكتين و كلازن روند زمينه نفروياتى را القاء مى كند. و تكامل كليه را با تبديل سلول هاى إيى تليال به مزانشيم و بيان فاكتور رشد بافت همبند در ايى تليوم كليوى تحت تاثير قرار مى دهد و آسيب توبولار و مجموع محتويات كلازن را در نوزادانى كه از مادران نيكوتينى متولد شدند

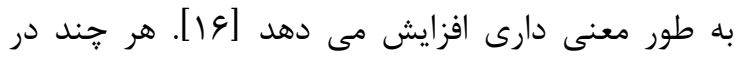

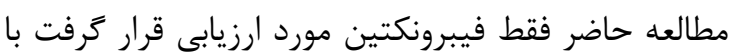
اين وجود به نظر مى رسد با افزايش فيبرونكتين كه خود

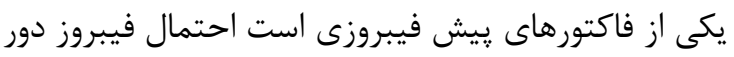

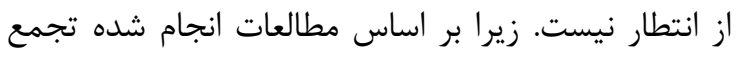

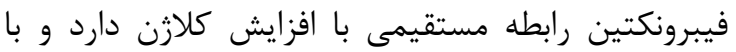

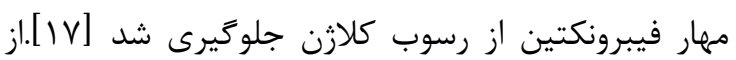
مكانيسم هاى ديكرى كه به نظر مي رسير رسد نيكوتين عامل

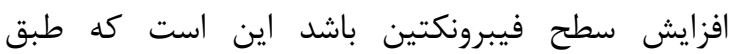
مطالعات انجام شده سطح فاكتورهاى التهابى سروم رابطه

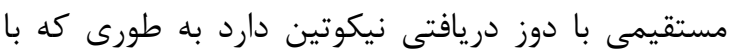

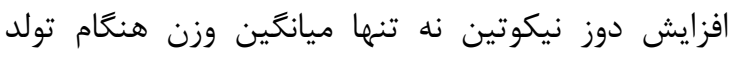

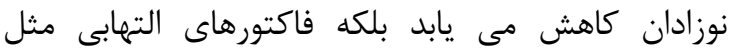

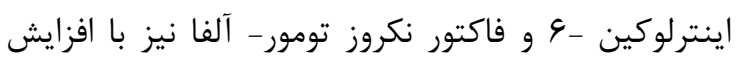
دوز نيكوتين هم خوانى دارد و سطح سرومى فاكتور

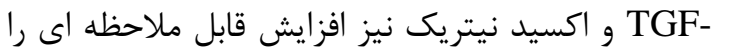

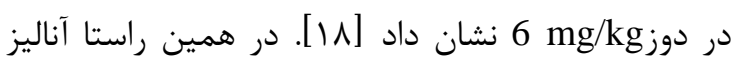

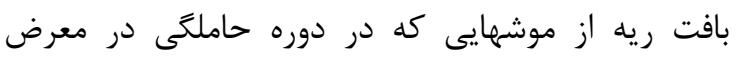

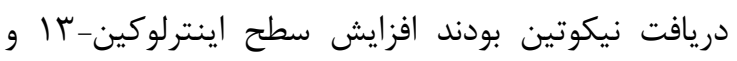
فاكتور TGF- را دار نشان داد كه فعاليت فاكوسيتى

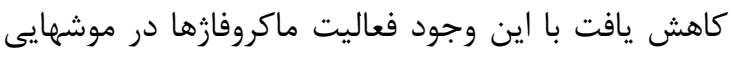

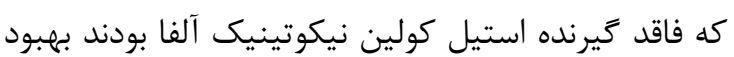

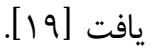

\section{نتيجه كيرى}

به نظر مى رسد نيكوتين موجود درسيكار با تحريك

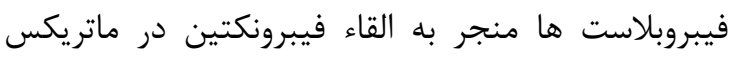
خارج سلولى كليه مى شود كه خود احتمال كاهش ميزان

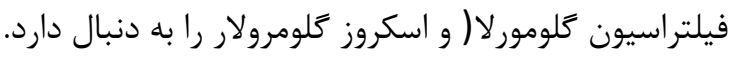

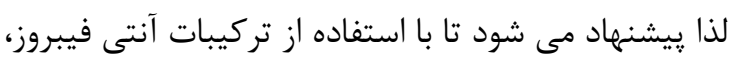

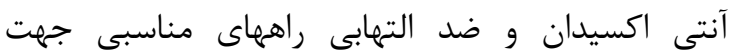
بيشكيرى از اثرات فيبروتيك نيكوتين مادرى كشف شود.
كاهش رشد اسكلت جنين مى شود و از سنتز ماتريكس

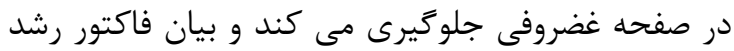

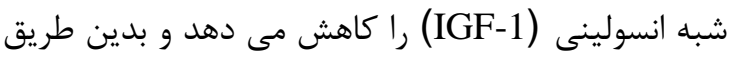
با تاخير در فرايند كوندروزنز باعث كاهش رشد و در نتيجه كاهش وزن هنغام تولد مى شود [ها]. كه نتايج مطالعه حاضر نيز با يافته هاى آنها مطابقت داشت.

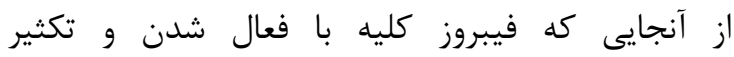
فيبروبلاست هاى بينابينى و سنتز بيش از حد اجزاء ماتريكس خارج سلولى همراه است اين امر باعث القاء

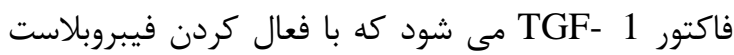

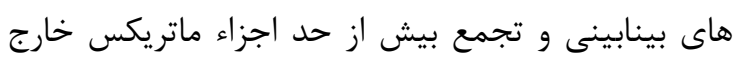
سلولى از قبيل فيبرونكتين و كلازن اتفاق مى افتد. اثرات آندات بيولوزيك اين فاكتور از طريق سيكنال هاى يايين دست

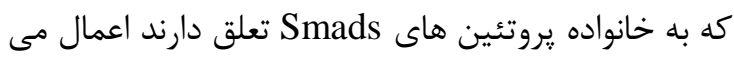

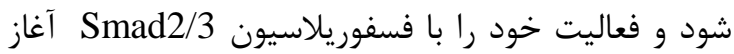

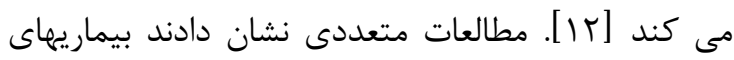

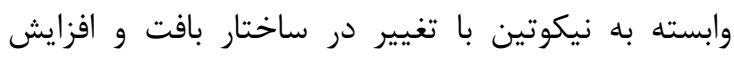
رسوب ماتريكس خارج سلولى همراه است. از جمله نيكوتين بيان فاكتور رشد مبدل بتا و رسوب كلازن رادر دران

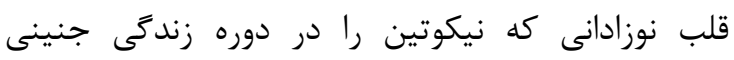

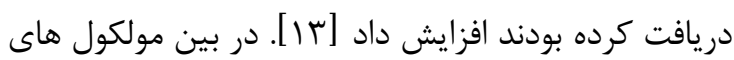
ماتريكس فيبرونكتين به نسبت زيادى در افراد سيخارى

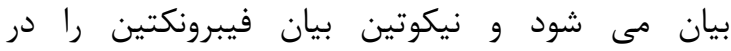
فيبروبلاست ها با فعال كردن سيخنال هاى داخل فيك سلوني منجر به افزايش بيان زن فيبرونكتين مى شود. و اثرات تحريكى نيكوتين با اكتيواسيون يروتئين كيناز ل يروتئين كيناز فعال كننده ميتورن همراه است كه سطح بأين

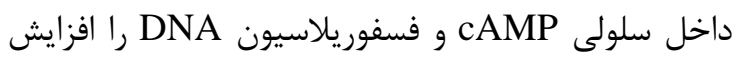
مى دهد و افزايش رونويسى زن به عناصر ياسخ دهنده به

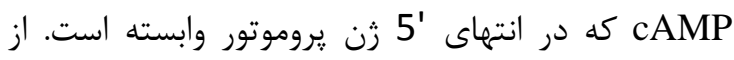

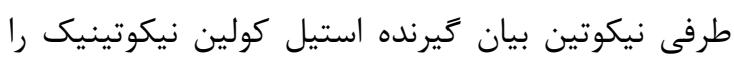

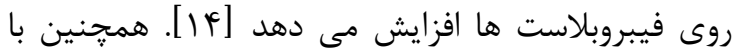
تجويز نيكوتين به موشهاى صحرايى بيان گيرنده نيكوتينى در سلول هاى كبدى و كلانزيوسيت ها بيان فاكتورهاى فئي ييش فيبروزى و فيبرونكتين افزايش يافت [ها] مى رسد نيكوتين با تكثير سلول هاى مزانزيال و افزايش بيان سيتوكين هاى ييش فيبروزى از قبيل فاكتور رشد نائ 


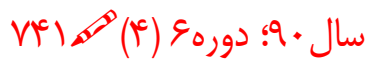

مجله دانشًاه علوم يزشكى خراسان شمالى

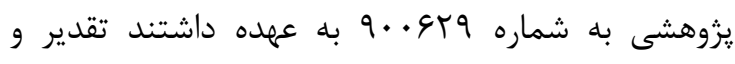

تشكر به عمل مى آيد.
تشكر و قدردانى

بدين وسيله از معاونت يزوهشى دانشعاه علوم يزشكى مشهد كه حمايت مالى اين طرح را بر اساس طرح 


\section{References}

1.Nielsen C.H., A. Larsen, A.L. Nielsen, DNA methylation alterations in response to prenatal exposure of maternal cigarette smoking: A persistent epigenetic impact on health from maternal lifestyle? Arch Toxicol, 2014.

2.Biederman J.," et al", Is Maternal Smoking During Pregnancy a Risk Factor for Cigarette Smoking in Offspring? A Longitudinal Controlled Study of ADHD Children Grown Up, J Atten Disord, 2014.

3.Baroni, T., "et al", Human cleft lip and palate fibroblasts and normal nicotine-treated fibroblasts show altered in vitro expressions of genes related to molecular signaling pathways and extracellular matrix metabolism, J Cell Physiol, 2010, 222(3): p. 748-56.

4.Votavova H., "et al", Deregulation of gene expression induced by environmental tobacco smoke exposure in pregnancy, Nicotine Tob Res, 2012, 14(9): p. 1073-82.

5.Deng Y., "et al", Nicotine-induced retardation of chondrogenesis through down-regulation of IGF-1 signaling pathway to inhibit matrix synthesis of growth plate chondrocytes in fetal rats, Toxicol Appl Pharmacol, 2013, 269(1): p. 25-33.

6.Mahdi Shariati K., "et al", Effects of maternal nicotine exposure on expression of laminin alpha 5 in lung tissue of newborn, Pak J Biol Sci, 2012, 15(24): p. 1168-75[Persian].

7.Sebinger D.D., "et al", ECM modulated early kidney development in embryonic organ culture, Biomaterials, 2013, 34(28): p. 6670-82.

8.Chakkarwar V.A., Smoking in diabetic nephropathy: sparks in the fuel tank? World J Diabetes, 2012; 3(12): p. 186-95.

9.Jalali M., "et al", Effects of Maternal Nicotine Exposure on Expression of Collagen Type IV and its Roles on Pulmonary Bronchogenesis and Alveolarization in Newborn Mice, Iran J Allergy Asthma Immunol, 2010. 9(3): p. 169-73[Persian].

10.Jung D.S., "et al", FR167653 inhibits fibronectin expression and apoptosis in diabetic glomeruli and in high-glucose-stimulated mesangial cells, Am J Physiol Renal Physiol, 2008;295(2): p. F595604.

11.Feng J.H., "et al", Maternal and fetal metabonomic alterations in prenatal nicotine exposureinduced rat intrauterine growth retardation, Mol Cell Endocrinol, 2014; 394(1-2): p. 59-69.

12.Zhou X., "et al", Curcumin Ameliorates Renal Fibrosis by Inhibiting Local Fibroblast Proliferation and Extracellular Matrix Deposition, J Pharmacol Sci, 2014.

13.Chou H.C, C.M. Chen, Maternal nicotine exposure during gestation and lactation induces cardiac remodeling in rat offspring, Reprod Toxicol, 2014. 50: p. 4-10.

14.Roman J., "et al", Nicotine and fibronectin expression in lung fibroblasts: implications for tobaccorelated lung tissue remodeling, FASEB J, 2004;18(12): p. 1436-8.

15.Jensen K.," et al", Chronic nicotine exposure stimulates biliary growth and fibrosis in normal rats, Dig Liver Dis, 2013; 45(9): p. 754-61.

16.Chen C.M., H.C. Chou, L.T. Huang, Maternal nicotine exposure during gestation and lactation induces kidney injury and fibrosis in rat offspring, Pediatr Res, 2015; 77(1-1): p. 56-63.

17.Miller C.G., "et al", Effects of high glucose on integrin activity and fibronectin matrix assembly by mesangial cells, Mol Biol Cell, 2014; 25(16): p. 2342-50.

18.Mohsenzadeh Y., "et al", Prenatal exposure to nicotine in pregnant rat increased inflammatory marker in newborn rat, Mediators Inflamm, 2014; 2014: p. 274048[Persian].

19. Wongtrakool C., "et al", In utero nicotine exposure promotes M2 activation in neonatal mouse alveolar macrophages, Pediatr Res, 2012; 72(2): p. 147-53. 


\title{
Effect of prenatal nicotine exposure on fibronectin changes of extracellular matrix in kidney
}

\author{
Pahang $H^{1}$, Behnamfar $M^{2}$, Nikravesh $M^{3} *$, jalali $M^{3}$
}

${ }^{1} \mathrm{Ph} . \mathrm{D}$ of anatomy, Department of Anatomy, Faculty of Medicine, North Khorasan University of Medical Sciences, Bojnord, Iran.

${ }^{2}$ students of medicines, Faculty of Medicine, North Khorasan University of Medical Sciences, Bojnord, Iran.

${ }^{3} \mathrm{PhD}$ of anatomy, Department of Anatomy and cell biology, Faculty of Medicine, Mashhad University of Medical Sciences, mashhad, Iran.

*Corresponding author : Mohammad Reza Nikravesh, Department of Anatomy and Cell Biology, Medical Faculty, Mashhad University of Medical Sciencesin Iran.

E-mail: Nikraveshmr@mums.ac.ir

\section{Abstract}

Background \& Objectives: Despite the serious effects of smoking, about 25 to $30 \%$ of women interest to smoke during pregnancy. Nicotine interfere the developmental process. The aim of this study was to evaluate the maternal nicotine effects on fibronectine expressions in newborn kidney extracellular matrix.

Material and Method: eighteen pregnant mice were used for this study that followed to the E6 day. To mice in experimental group 3mg/kg /day nicotine and to ones in control $3 \mathrm{ml} / \mathrm{kg} /$ day normal saline administrated intraperitoneally. On the first day of delivery the left Neonatal kidney tissue was used for Immunohistochemistry(IHC) examination and right kidney for RT-PCR test.

Results: THE IHC results that analyzing with kruskal walis showed fibronectine accumulated significantly in glomerule and proximal convoluted tubule matrix in mice received nicotine $(P<0.05)$. The $R T-P C R$ results proved this finding.

Conclusion: Nicotine induces the production of Fibronectin in kidney extracellular matrix that reduce the Possibility of Glomerular filtration rate and glomerular sclerosis.

Key words: nicotine, fibronectine, kidney, extracellular matrix 